\title{
Special Agricultural Safeguards: Virtual Benefits and Real Costs-Lessons for the Doha Round
}

\author{
Jean-Jacques Hallaert
}




\title{
IMF Working Paper
}

Policy Development and Review Department

\section{Special Agricultural Safeguards: Virtual Benefits and Real Costs-Lessons for the Doha Round}

\author{
Prepared by Jean-Jacques Hallaert ${ }^{1}$
}

Authorized for distribution by Hans Peter Lankes

June 2005

\begin{abstract}
This Working Paper should not be reported as representing the views of the IMF. The views expressed in this Working Paper are those of the author(s) and do not necessarily represent those of the IMF or IMF policy. Working Papers describe research in progress by the author(s) and are published to elicit comments and to further debate.

In the Doha Round, negotiators are discussing the elimination or continuation of the special agricultural safeguards introduced by the Uruguay Round as well as the creation of special safeguard mechanism for use by developing countries. This paper argues that, in violation of the spirit of the WTO Agreement in Agriculture, the special agricultural safeguards have often been used as a prolonged protectionist device. It then draws lessons for the design of the special safeguard mechanism.

JEL Classification Numbers: F13, Q17
\end{abstract}

Keywords: Agricultural trade, safeguards, trade policy

Author(s) E-Mail Address: jhallaert@imf.org

\footnotetext{
${ }^{1}$ The author is with the Trade Policy Division of the IMF's Policy Development and Review Department. The author would like to thank Hans Peter Lankes for his comments and Patrick A. Messerlin for his support and suggestions. All errors and omissions remain the sole responsibility of the author.
} 


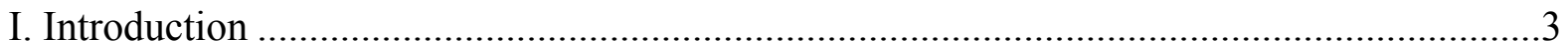

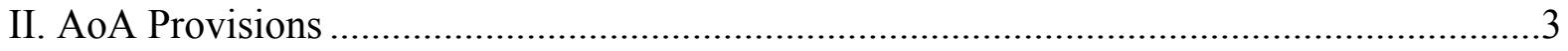

III. The Implementation of the Special Safeguards: An Emerging Pandemic.........................4

A. Special Safeguards Are Frequently Invoked........................................................4

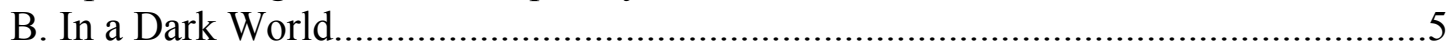

C. The Shift to Permanent Protection .................................................................. 6

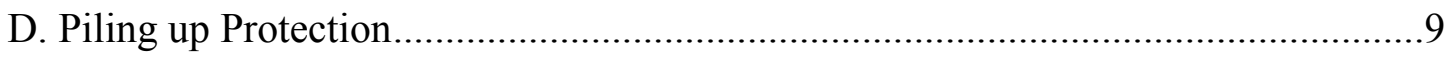

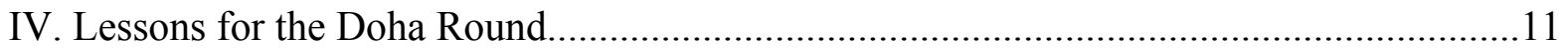

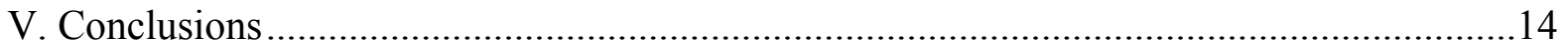

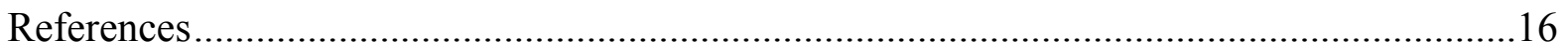

Tables

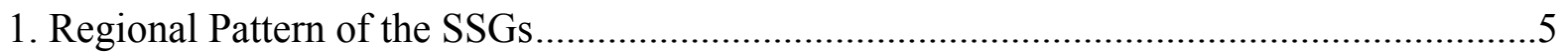

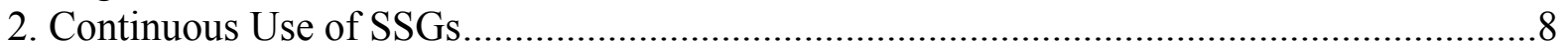

3. EC - Overlap of Potential SSGs with Other Types of Protections ................................. 10

Figures

1. Additional Duties Reported in Notifications to the WTO ..............................................6

2. EC — Share of Imports Affected by Special Safeguards (value) .......................................9

3. One Option of the Japanese Proposal ...........................................................................13

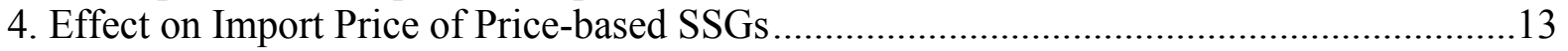

Appendices

I. Formula for the Calculation of the Additional Duty .................................................... 18

II. Notifications to the WTO ....................................................................................... 19

III. Share of Agricultural Lines for Which Countries Have Reserved the Right to Have

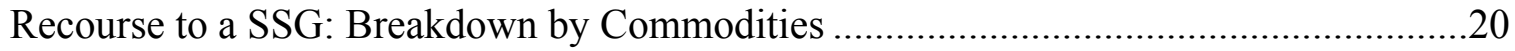

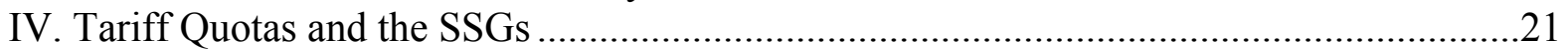




\section{INTRODUCTION}

Agricultural safeguards have emerged as an important issue in the Doha Round negotiations on farm trade. Many developing countries (the "Alliance for Strategic Products and Special Safeguard Mechanism," the CARICOM, the G20, the Like-Minded Group of developing countries, and others) have backed the creation of a Special Safeguard Mechanism (SSM), which could be used only by developing countries. Some of them have even stressed that no agreement on agricultural trade would be viable if special products ${ }^{2}$ and an SSM were not included as integral parts of the market access package. Thus, negotiators have been discussing the elimination or continuation of the Special Agricultural Safeguards (SSGs) introduced by the Uruguay round Agreement on Agriculture (AoA) as well as the creation of an SSM.

This paper analyzes how SSGs have been implemented, and draws lessons for the SSM. ${ }^{3}$ After describing briefly the AoA provisions governing the SSGs, the paper quantifies the volume of agricultural trade they affect and assesses the protection they provide. There are four main findings:

- First, the SSGs are no longer a prerogative of rich countries: transition economies and developing countries are increasingly using them.

- Second, the SSGs are used to protect almost continuously a small number of commodities. This is in clear violation of the spirit of the AoA.

- Third, the SSGs provide an additional protection to commodities that are already heavily protected by restrictive tariff quotas and specific or mixed duties.

- Fourth, the SSGs are applied in such a way that they reduce the transparency of tariff schedules and introduce a new element of unpredictability in market access.

Therefore, in light of past experience, the SSGs should be eliminated and the creation of the SSM avoided. However, since WTO members have agreed to create the SSM, the paper also discusses its design stressing provisions that would ensure that it does not become a protectionist device. ${ }^{4}$

\section{AoA Provisions}

The possibility to invoke special safeguards was introduced in the Uruguay Round Agreement on Agriculture (Article 5) in order to secure a greater market opening. The AoA tried to improve market access by substituting tariffs for nontariff barriers (NTBs) such as quotas and import bans. However, some countries feared that the reform would trigger domestic market disruptions. Thus, in order to address temporary shocks during the transition

\footnotetext{
2 Some agricultural products are considered sensitive. For these "special products," developing countries would be provided with flexibilities with respect to their commitments, in particular tariff cut would be smaller than for other products.

${ }^{3}$ Lessons could also be drawn for preferential trade agreements. Some of them, such as the Chile-US free trade agreement, have provisions for price-based agricultural safeguards similar to the SSGs (WTO, 2004a).
}

${ }^{4}$ The package adopted by WTO members on August 1, 2004 indicates that as part of the Doha Round "a Special Safeguard Mechanism (SSM) will be established for use by developing country members." (WTO, 2004b) 
to a tariff-only regime, it was agreed that WTO members "tariffying" their NTBs could invoke the SSGs. The SSGs were to expire when such a move was completed. However, trade policy history shows that temporary exceptions and protections are extremely difficult to eliminate. The SSGs are no exception: their extension is now being discussed in the Doha Round.

The SSGs take the form of an additional duty, which can be imposed only when four conditions are met. First, the additional duty can only be imposed on tariffied products for which a reservation appears in the member's tariff schedule. The share of this reservation varies significantly across countries: from less than 0.5 percent of the agricultural tariff lines for New Zealand and Uruguay to 66 percent for Poland (Appendix II).

Second, as detailed in Appendix I, the additional duty can be imposed if the value of imports falls below a reference price (price-based SSGs) or when the volume of imports surges (volume-based SSGs).

Third, the additional duty cannot affect the minimum access commitments and cannot be applied to imports taking place within tariff quotas.

Fourth, in order to ensure transparency, the use of the SSGs should be notified to the WTO before the action is implemented (in any event no later than 10 days after the action is taken).

Because these conditions are less stringent than those attached to regular safeguards, the SSGs are easier and cheaper to invoke. Easier because no proof of injury is required. Cheaper, because the administrative costs of the procedure are limited and no compensation is required.

\section{The Implementation of the Special SAFEguARds: An EMERging PandeMiC}

At first glance, the impact of the SSGs appears limited. Only 39 WTO members ${ }^{5}$ can invoke them, for only a (usually) small part of their agricultural imports. Moreover, so far, only 13 WTO members have actually implemented them (Appendix II). However, this section shows that special safeguards have become a protectionist device sheltering a few sensitive commodities.

\section{A. Special Safeguards Are Frequently Invoked}

As of end-May 2005, 1,477 SSGs were notified to the WTO. The number of SSGs actually implemented was higher because often WTO members ignore the AoA notification requirements (Appendix II). For example, Republic of Korea had not notified the SSGs it had been implementing since 2001, the European Communities (EC) since 2002, ${ }^{6}$ the United States since 2003. These three WTO members accounted for more than 70 percent of all the SSGs notified during 1995-2000.

Initially, the SSGs were mostly used by rich countries, but transition economies and developing countries have recently started to invoke them frequently. Until 1998, the EC,

\footnotetext{
${ }^{5}$ The number of eligible WTO members increased from 38 to 39 upon the accession of the "Separate Customs Territory of Taiwan, Penghu, Kinmen and Matsu" (hereafter Taiwan Province of China).

${ }^{6}$ In its notifications to the WTO, the EC indicates that the price-based safeguards were made operational, whereas the volume-based safeguards were "made operational" but were not "invoked" (WTO, 2002a).
} 
Japan, and the United States accounted for more than 90 percent of the SSGs invoked. Starting in 1999, their share dropped because Central European countries had increasingly resorted to the SSGs (Table 1). Moreover, starting in 2002, the number of developing countries invoking the SSGs increased: Republic of Korea and Costa Rica were joined by Barbados, Nicaragua, and the Philippines. The same year, Taiwan Province of China joined the WTO and implemented a large number of SSGs (Appendix II).

Table 1. Regional Pattern of the SSGs (percent of all SSGs notified to the WTO in a given year) ${ }^{1 /}$

\begin{tabular}{lllllll}
\hline & 1995 & 1996 & 1997 & 1998 & 1999 & 2000 \\
\hline EC, Japan, United States, & 92 & 95 & 91 & 90 & 38 & 69 \\
Switzerland & 0 & 0 & 0 & 0 & 3 & 0 \\
Transition economies & 0 & 1 & 3 & 5 & 54 & 14 \\
Republic of Korea and Costa Rica & 8 & 3 & 6 & 5 & 4 & $17^{2 /}$ \\
\hline
\end{tabular}

Source: Author's calculation based on notifications to the WTO.

1/ Shares for the period 2001-04 cannot be calculated because key players did not notified their SSGs.

2/ Costa Rica has not yet provided any notification for 2000 although some SSGs were implemented.

\section{B. In a Dark World}

Most WTO members have resorted to the SSGs in violation of the AoA requirements on transparency. Notifications are not provided before or upon the implementation of the SSGs but after, and usually with a substantial lag. Moreover, some WTO members ignore the obligation that a reservation to use special safeguards must appear beside the products concerned in the member's schedule. ${ }^{7}$

The additional duty is also difficult to estimate. WTO rules do not require to notify the additional duty, and to date, only Costa Rica, Nicaragua, and the Slovak Republic have done so. These countries account for only 0.6 percent of all notifications and it is therefore impossible to draw general conclusions. However, it appears that in these cases, the additional duty was substantial: 24 percent on average, which added to an already high MFN tariff of 43 percent (Figure 1).

In addition to reducing transparency, the SSGs allow a country to escape its obligations regarding the tariff binding. The additional duty can lead to a total tariff higher than the bound rate. The rationale of this provision is that during the tariffication process, countries were concerned that the binding would limit their ability to increase tariffs to face market instability. Regular safeguards offer the same possibility, ${ }^{8}$ but appear less damaging because, in sharp contrast with the SSGs, they are rarely invoked: about 150 regular safeguards were

\footnotetext{
${ }^{7}$ For example, the tariff schedule published in the Official Journal of the European Communities (2001) does not mention the possibility of a special safeguard.

${ }^{8}$ Article XIX of the GATT 1994 and the Agreement on Safeguards, which set forth the rules for application of safeguard measures, allow resort to quantitative import restrictions or duty increases to higher than bound rates if an increase in imports of particular products has caused or threatens to cause serious injury to the importing member's domestic industry. Unlike the SSGs, a fall in prices is not considered.
} 
invoked during the 50 years of the GATT, while almost 10 times more SSGs have been implemented in just 9 years. ${ }^{9}$

Figure 1. Additional Duties Reported in Notifications to the WTO

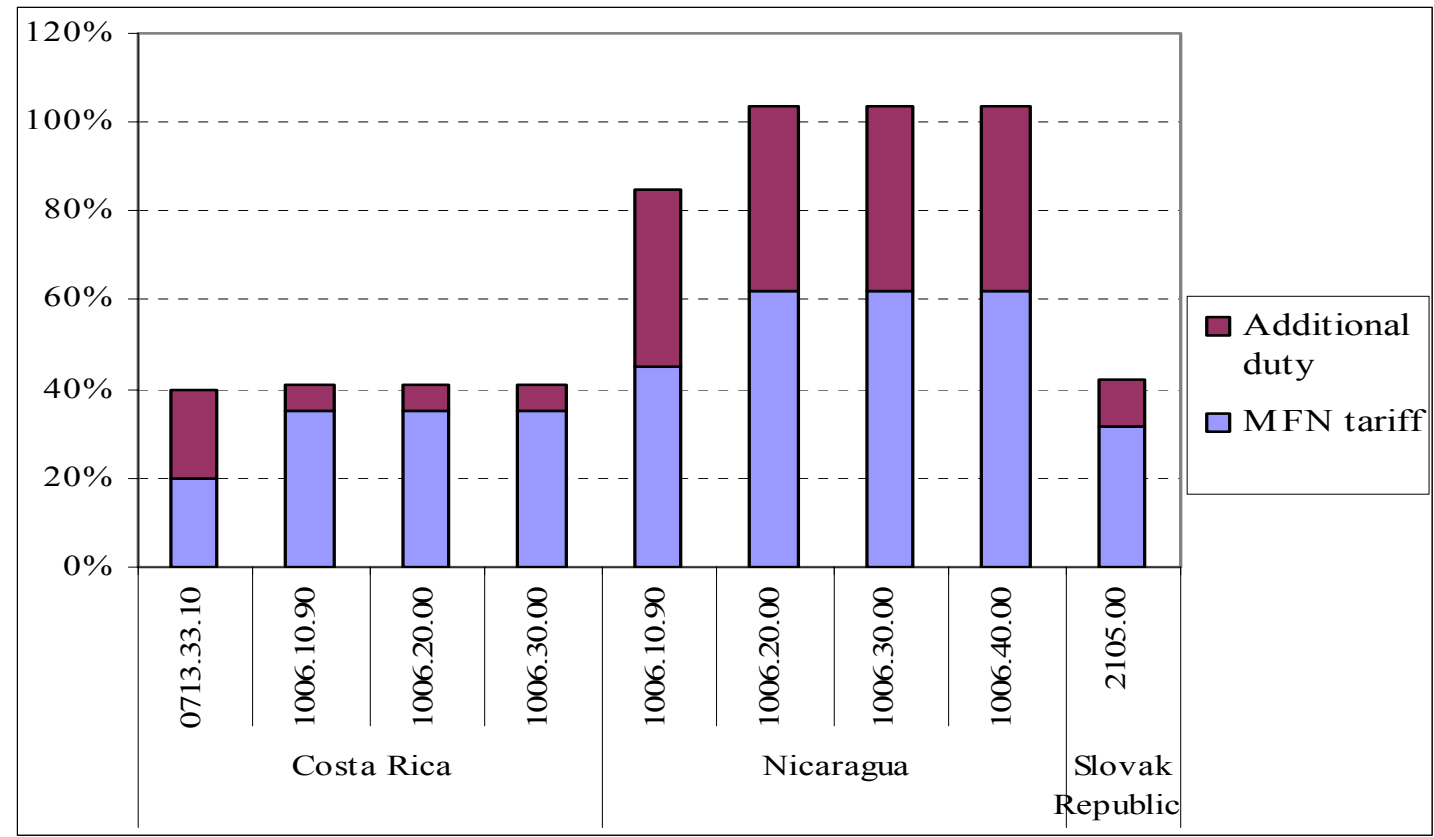

Source: Notifications to the WTO.

Notes: 1/ Price-based SSGs in the case of Costa Rica and Nicaragua and volume-based SSGs in the case of the Slovak Republic.

2/ Tariff line 0713.33 .10 refers to black beans, line 1006 to rice, and line 2105 to ice cream and other edible ice.

Costa Rica provides an example of the use of the SSGs to escape the obligation of the bound tariff. In 1995, in response to low-priced rice imports, Costa Rica increased its tariff from about 14 percent on average to the bound level of 35 percent (ERS/USDA). Then, instead of going through the long and costly process of debinding, it had recourse to a price-based SSG. In their notification, the authorities estimated that the additional duty would push the total tariff to 40-41 percent (Figure 1). However, according to Oryza (2002), the total tariff reached 54 percent.

\section{The Shift to Permanent Protection}

The case of Costa Rica also illustrates that the SSGs are not used as a tool of temporary protection. Costa Rica maintained the SSGs in place from November 1999 to February 2002; but no notification was provided to the WTO for 2001 and 2002. In February 2002, a regular safeguard replaced the price-based SSG and the total tariff increased further reaching 71

\footnotetext{
${ }^{9}$ There are several reasons why regular safeguards have been rarely used. In particular, Article XIX requires a lengthy and costly process (in part to prove a threat of injury) as well as the need to compensate WTO partners.
} 
percent. In March 2002, the country placed a temporary import duty of 80 percent on paddy rice imported from the United States through the application of Article XIX. Then, in October 2002, the price-based SSG was put back in place (at that time no estimated additional duty was included in the notification) and the sanitary and quality inspection fee was almost doubled to \$19 / MT (Oryza, 2002; FAO, 2003).

Tables 2 shows that Costa Rica is not an isolated case. Most WTO members use the SSGs to protect some commodities over several years. Examples are plentiful, but perhaps the most obvious case is Hungary which imposed a continuous safeguard on sugar from end-May 1999 to end-April 2004. In that date Hungary joined the EU and so took over the EU trade regime including its SSGs. This continuous use of special safeguards violates the spirit of the AoA and shows that they are not imposed to face temporary shocks but as a protectionist device. 
Table 2. Continuous Use of SSGs (percent of tariff lines for which SSGs are activated in one year that are also subject to SSGs in the following years, 1995-2004) ${ }^{1 /}$

\begin{tabular}{|c|c|c|c|c|c|c|c|c|c|c|}
\hline & & $\mathrm{N}+1$ & $\mathrm{~N}+2$ & $\mathrm{~N}+3$ & $\mathrm{~N}+4$ & $\mathrm{~N}+5$ & $\mathrm{~N}+6$ & $\mathrm{~N}+7$ & $\mathrm{~N}+8$ & $\mathrm{~N}+9$ \\
\hline \multirow[t]{3}{*}{1995} & $\mathrm{EC}^{2 /}$ & 92 & 92 & 92 & 92 & 92 & 92 & - & - & - \\
\hline & Japan & 25 & 0 & 0 & 25 & 0 & 0 & 0 & 25 & 25 \\
\hline & United States & 50 & 70 & 65 & 30 & 40 & 35 & 40 & - & - \\
\hline \multirow[t]{3}{*}{1996} & $\mathrm{EC}$ & 69 & 92 & 90 & 90 & 92 & - & - & - & \\
\hline & Japan & 8 & 3 & 3 & 11 & 17 & 3 & 3 & 3 & \\
\hline & United States & 83 & 88 & 40 & 40 & 31 & 46 & - & - & \\
\hline \multirow[t]{4}{*}{1997} & $\mathrm{EC}$ & 85 & 83 & 83 & 85 & - & - & - & & \\
\hline & Japan & 60 & 60 & 20 & 40 & 0 & 20 & 0 & & \\
\hline & Republic of Korea & 86 & 86 & 100 & - & - & - & - & & \\
\hline & Poland & 50 & 75 & 25 & 25 & 25 & 0 & 25 & & \\
\hline \multirow{3}{*}{1998} & Republic of Korea & 86 & 100 & - & - & - & - & & & \\
\hline & Poland & 83 & 0 & 17 & 17 & 17 & 33 & & & \\
\hline & United States & 29 & 31 & 29 & 41 & - & - & & & \\
\hline \multirow[t]{8}{*}{1999} & Costa Rica & $-3 /$ & $-3 /$ & 75 & - & & & & & \\
\hline & $\mathrm{EC}$ & 100 & 100 & - & - & - & & & & \\
\hline & Hungary & 100 & 100 & 100 & 100 & 57 & & & & \\
\hline & Japan & 44 & 11 & 11 & 56 & 33 & & & & \\
\hline & Republic of Korea & 100 & - & - & - & - & & & & \\
\hline & Poland & 2 & 0 & 91 & 0 & 7 & & & & \\
\hline & Switzerland & 0 & 0 & 0 & 0 & 0 & & & & \\
\hline & United States & 57 & 69 & 71 & - & - & & & & \\
\hline 2000 & $\mathrm{EC}$ & 100 & - & - & - & & & & & \\
\hline 2001 & United States & 68 & - & - & & & & & & \\
\hline \multirow[t]{5}{*}{2002} & Czech Republic & 67 & - & & & & & & & \\
\hline & Hungary & 100 & 57 & & & & & & & \\
\hline & Japan & 75 & 38 & & & & & & & \\
\hline & Poland & 4 & 9 & & & & & & & \\
\hline & Taiwan Province of China & 49 & 28 & & & & & & & \\
\hline \multirow[t]{4}{*}{2003} & Hungary & 57 & & & & & & & & \\
\hline & Japan & 50 & & & & & & & & \\
\hline & Poland & 67 & & & & & & & & \\
\hline & Taiwan Province of China & 69 & & & & & & & & \\
\hline
\end{tabular}

Source: Author's calculation based on notifications to the WTO as of end-May, 2005.

$1 /$ "-" indicates that no notification has been made for the specific year.

2/ 92 percent in $\mathrm{N}+1$ to $\mathrm{N}+6$ in the case of the EC indicates that 92 percent of products subject to a safeguard in 1995 were subject to a safeguard in $1996(\mathrm{~N}+1)$ to $2001(\mathrm{~N}+6)$.

3/ Costa Rica maintained safeguards in 2000 and 2001 but has not (yet) notified them to the WTO. 


\section{Piling up Protection}

The special safeguards tend to protect a few sensitive commodities. For example, the EC has reserved the right to invoke them for most types of agricultural goods (Appendix III) but has notified to the WTO the activation of the SSGs for only three types of commodities: sugar, fruits and vegetables, and meat. ${ }^{10}$ As a result, while the notified SSGs covered only about 5 percent of the EC's imports of agricultural goods during 1996-2001, they affected almost all its imports of sugar (Figure 2).

Figure 2. EC-Share of Imports Affected by Special Safeguards (value)

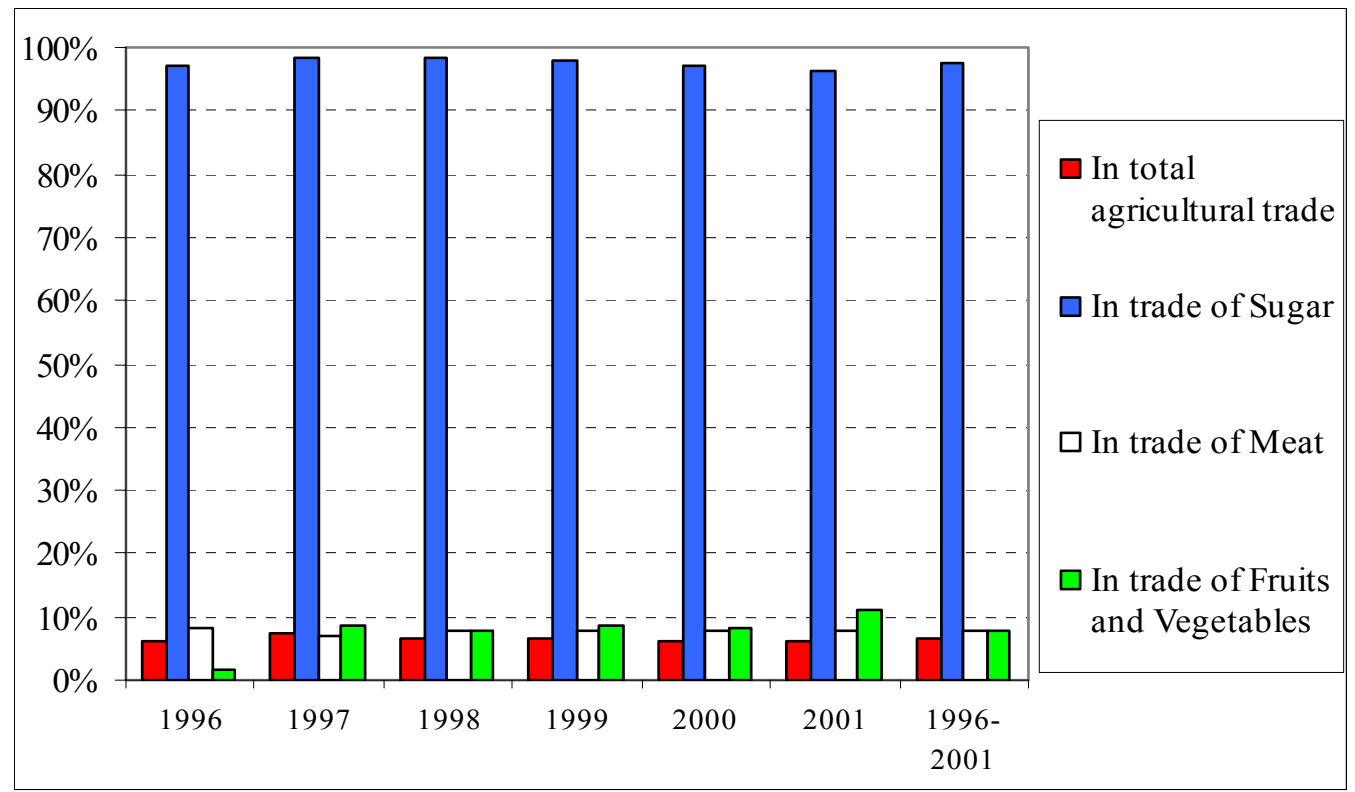

Source: Author's calculation.

Note: Shares calculated at HS-8 digit level.

These commodities often benefit from substantial subsidies. For example, the OECD estimates that the EC's total support to sugar accounted to 51 percent of total gross farm receipts on average over 1999-2001.

These commodities are also protected by high barriers to entry. First, the SSGs often provide commodities already sheltered by specific and seasonal duties with additional protection. These duties are usually high and non-transparent. The WTO (2004c) estimates that the ad valorem equivalent of the EC specific duty on beet sugar reaches 114.4 percent. ${ }^{11}$ Table 3 reports that virtually all tariff lines for which the EC has reserved the right to invoke special safeguards are protected by mixed or specific duties. There are only four exceptions and in three of them a seasonal tariff is levied. This pattern is not unique. For example, Japan can invoke the SSGs on 56 percent of the tariff lines it protects with specific or mixed tariffs. ${ }^{12}$

\footnotetext{
${ }^{10}$ The EC also notified a special safeguard on eggs in 1995.

${ }^{11}$ Duties on meat exceeding 100 percent are numerous.

${ }^{12}$ In contrast with the EC, Japan does not apply safeguard on lines protected by seasonal tariffs.
} 
Table 3. EC-Overlap of Potential SSGs with Other Types of Protections (2002, in percent)

\begin{tabular}{lcccccc}
\hline & \multicolumn{3}{c}{ Share of SSG lines facing } & \multicolumn{3}{c}{ Share of non-SSG lines facing } \\
\cline { 2 - 7 } & $\begin{array}{c}\text { Specific or } \\
\text { mixed } \\
\text { tariffs }\end{array}$ & $\begin{array}{c}\text { WTO } \\
\text { Tariff rate } \\
\text { Quotas }\end{array}$ & $\begin{array}{c}\text { Seasonal } \\
\text { tariffs }\end{array}$ & $\begin{array}{c}\text { Specific or } \\
\text { mixed } \\
\text { tariffs }\end{array}$ & $\begin{array}{c}\text { WTO } \\
\text { Tariff rate } \\
\text { Quotas }\end{array}$ & $\begin{array}{c}\text { Seasonal } \\
\text { tariffs }\end{array}$ \\
\hline ALL & 99 & 38 & 4 & 26 & 2 & 1 \\
Meat & 100 & 54 & 0 & 9 & 5 & 0 \\
Dairy products & 100 & 34 & 0 & 93 & 10 & 0 \\
Eggs & 100 & 75 & 0 & 0 & 0 & 0 \\
Cereals & 99 & 27 & 0 & 86 & 0 & 0 \\
Fruits and vegetables & 95 & 45 & 60 & 13 & 2 & 3 \\
Oil seeds, fats and oils, and products & 100 & 0 & 0 & 0 & 0 & 0 \\
Sugar and confectionery & 100 & 43 & 0 & 82 & 6 & 0 \\
Coffee, tea, maté, cocoa, spices, and & 100 & 0 & 0 & 33 & 0 & 0 \\
$\quad$ food preparations & 100 & 33 & 0 & 54 & 2 & 0 \\
Beverages and spirits & n.a. & n.a. & n.a. & 70 & 0 & 0 \\
Tobacco & n.a. & n.a. & n.a. & 0 & 0 & 0 \\
Agricultural Fibers & 96 & 16 & 0 & 1 & 0 & 3 \\
Other agricultural products & & & &
\end{tabular}

Source: Author's calculation.

Note: Calculated at HS-8 digit; n.a.: not applicable.

Second, the SSGs magnify the protectionist impact of tariff rate quotas (TRQ). Most countries that have reserved the right to invoke the special safeguards also maintain TRQs (Appendix IV). Since the additional duty can only be imposed on the over-quota imports, the SSGs further increase the protectionist impact of TRQs: in 2002, the over-quota average tariff for agricultural goods was 4.3 times higher than average bound tariff in the United States and 2.6 times higher in the EC. ${ }^{13}$ All price-based SSGs invoked by the United States (which account for 98 percent of the SSGs it invoked) are applied over-quota. Table 3 reports that about 40 percent of tariff lines on which the EC can impose special safeguards are already protected by a TRQ. ${ }^{14}$ Symmetrically, the EC has reserved the right to invoke the SSGs for 90 percent of agricultural tariff lines protected by a TRQ.

The protectionist use of the SSGs is even more obvious when countries invoke SSGs on products for which there are no imports. This is clearly protectionism because if there are no imports there cannot be an import surge and changes in world prices cannot disrupt domestic markets. Japan and Taiwan Province of China notified SSGs on products that were not imported at all. Japan did so for wheat starch, wheat flour, milk powder, some food preparations, and some dairy products. The absence of imports was likely due to very high protection: wheat flour was protected by a 25 percent tariff; dairy products were protected by

\footnotetext{
${ }^{13}$ See http://www.ers.usda.gov/db/Wto/. In 2004, the difference has decreased to 3.0 times higher for the United States and 2.5 times higher for the EC. The same year average over-quota tariff on agricultural commodities reached 35 percent in the United States compared to an average in-quota tariff of 10 percent. In the EC, they reached respectively 79 percent and 17 percent.

${ }^{14}$ The share reached about 50 percent if only the activated SSGs during 1995-2000 are taken into account.
} 
an ad valorem tariff higher than 20 percent and a specific duty; and food preparations as well as wheat starch were protected by a high specific duty. In 2002, Taiwan Province of China invoked five SSGs on commodities for which no imports were recorded in the past. Once again, protection was likely to be the main reason for the absence of imports: these commodities faced ad valorem import duties ranging from 133 to 216 percent and high specific duties. Despite the absence of any imports, Taiwan Province of China and Japan decided to increase further the protection by invoking the SSGs. Therefore, the design of the special agricultural safeguard appears flawed and open to abuse. ${ }^{15}$

In sum, in contrast with the original stated purpose, the SSGs are a protectionist device. Designed to facilitate tariffication and market opening, the SSGs have actually been used to protect a few commodities which already enjoy various types of protections. Thus, they have reduced the transparency and predictability of the tariff schedule. They should be eliminated and the creation of a similar safeguard for developing countries should be avoided. However, since the creation of an SSM has already been agreed, the next section discusses how to prevent that the SSM from becoming a protectionist device.

\section{LESSONS FOR THE DOHA ROUND}

Most proposals for an SSM suggest a design similar to the existing SSGs. Thus, the 2003 draft agricultural modalities indicated: "For Special products [...], developing countries shall have the flexibility to apply a special safeguard mechanism to be based on the provisions of Article 5 of the Agreement on Agriculture" (WTO, 2003a). In this section, we argue that the flaws that allowed to use the SSGs as a protectionist device need to be corrected in an SSM.

Like the SSGs during the Uruguay Round, an SSM can be seen as a way to ease concerns regarding tariff changes negotiated in the Doha Round. Several developing countries argue that binding more tariffs and cutting those that are already bound would limit their capacity to increase customs duties in a case of emergency leaving them without the possibility to protect their farmers since, unlike developed countries, they cannot offer large subsidies. ${ }^{16}$ These countries call for an SSM.

Developing countries also argue that regular safeguards require technical and legal capacities that most of them do not have. Thus, they ask for a system similar to the SSGs which does not require to justify the safeguards nor any compensation. This is in essence the argument of the CARICOM proposal: "Developing countries and Small Developing Countries have not found the Safeguard instruments under Article XIX and the Agreement on safeguards to be particularly effective due to the well known limitations, regarding their own resources and institutional capacity, and as well owing to the fact that the application of these measures

\footnotetext{
15 The design in the SSGs is supposed to prevent such cases: the smaller the ratio of imports over consumption $(\mathrm{M} / \mathrm{C})$ the larger the increase in imports has to be to trigger a special safeguard (Appendix II). However, when the ratio $\mathrm{M} / \mathrm{C}$ is very close to zero, an additional duty can almost immediately be applied.

${ }^{16}$ This is for instance the position taken by the 22 developing countries of the "The Alliance for Specific Products (SP) and Special Safeguards Mechanism (SSM)" in July 2003, at the last meeting of the Committee on Agriculture before the Cancùn Ministerial.
} 
(Article XIX and the Agreement on Safeguards) requires proof of injury and involves lengthy and costly legal processes" (WTO, 2002b). ${ }^{17}$

However, past experience with the SSGs shows that the absence of a justification and of any compensation leave the mechanism open to abuse and explain why, in contrast to regular safeguards, special safeguards have been frequently used. An SSM designed on the model of the SSGs would have the same fate. It would undermine the liberalization it is supposed to facilitate. ${ }^{18}$ Therefore, the SSM needs to be carefully designed.

In order to avoid the use of the SSM as a protectionist device, its design should have four main objectives. First, the additional tariff should take the form of an ad valorem tariff applied on a non-discriminatory basis. The use of quantitative restrictions, suggested by some WTO members such as the "friends of special products", should be ruled out. It would jeopardize the main achievement of the AoA: converting NTBs into ad valorem tariffs. Moreover, because quantitative restrictions would imply a discrimination between suppliers, the SSM would be more costly to manage, less transparent, and easier to use as a targeted protectionist device.

Second, market access should not be compromised. The previous section has shown that the SSGs have sometimes been invoked to prevent access to some closed markets. This abuse should be tackled in the new SSM. There is no obvious solution but it is clear that the criterion used for the SSGs (the ratio of imports over consumption-Appendix I) is inadequate. Not only did it not prevent abuses but it could not be calculated. Often, high and middle income countries invoking the SSGs indicated in their notifications to the WTO that they were unable to calculate the ratio because data were not available. There is no reason to believe that the situation would be better for developing countries.

Third, an SSM should only be used to address large, sudden, and temporary shocks. Therefore, it should preclude the continuous or almost continuous use of safeguards that allowed the SSGs to become a protectionist device. This can be achieved by explicitly limiting for each product the number of successive years or marketing periods the safeguard can be invoked as suggested by the CARICOM (WTO, 2002b). Another way is to request a proof of injury. Of course, the proof of injury attached to an SSM needs to be simpler than the one required for regular safeguards since otherwise there is no justification to create another mechanism and developing countries might be unable to use it.

Limiting the use of special safeguards to temporary shocks also implies that the SSM should not insulate agricultural markets from long-term trends. Agricultural policies of many OECD countries have shown that insulation leads to oversupply, misallocation of resources, and distortions. Nonetheless. some countries have proposed mechanisms that would insulate their agricultural sector. The most explicit is the Japanese proposal to create a new safeguard mechanism for seasonal and perishable products (MAFF, 2001). As an option, Japan suggests that a variable levy would prevent the drop of prices below a certain threshold (Figure 3). In contrast, the SSGs (Figure 4) allow smoothing price volatility without

\footnotetext{
${ }^{17}$ Many other reasons are put forward to justify the SSM; they range from food security to the stabilization of the income of subsistence farmers.

${ }^{18}$ Somwaru and Skully (2003) show that an SSM would also have adverse welfare implications.
} 
insulating the economy: the additional tariff does not fully offset the drop in prices and thus there is no guaranteed floor price or any insulation against long-term decline in world price.

Fourth, an SSM should enforce transparency requirements. The requirements attached to the SSGs appears adequate and the SSM could replicate them. However, they are often ignored facilitating a discrete and protectionist use of the SSGs. Therefore, the main challenge for the SSM is enforcement. Transparency is particularly important for the SSM because many developing countries face governance issues in their customs administration. In this context, a non-transparent additional duty may lead to further uncertainties, worsen valuation problems, promote bribery, and, undermine progress in trade facilitation. In this context, negotiators should consider to request countries invoking the SSM to notify the expected additional duty.

Figure 3. One Option of the Japanese Proposal

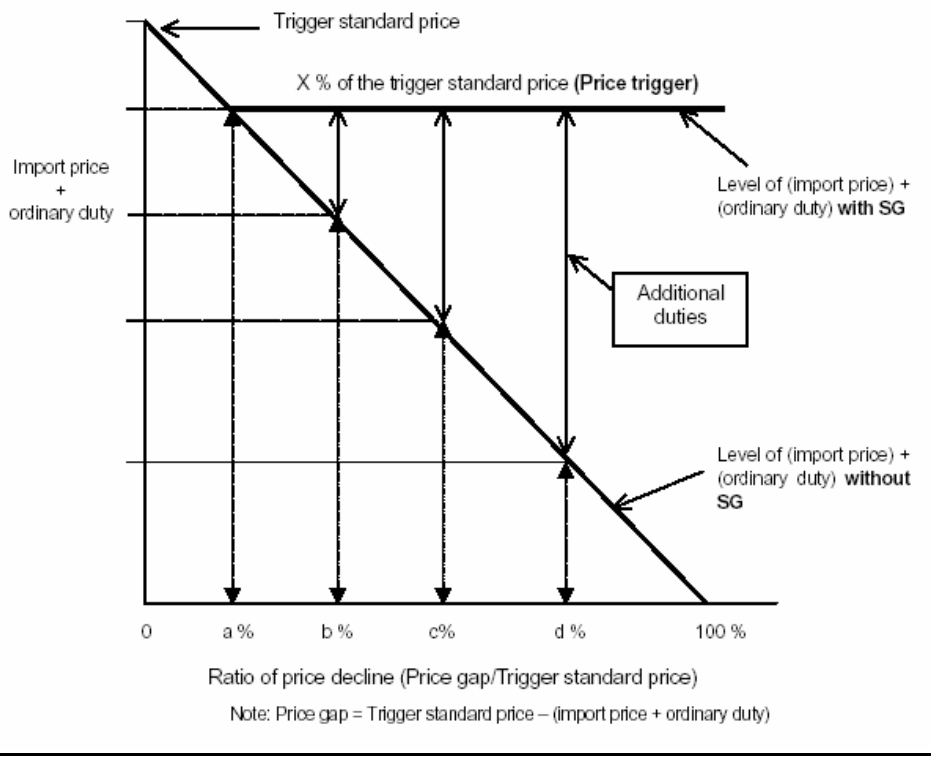

Source: MAFF (2001).

Figure 4. Effect on Import Price of Price-based SSGs (Assuming a trigger price of US\$100)

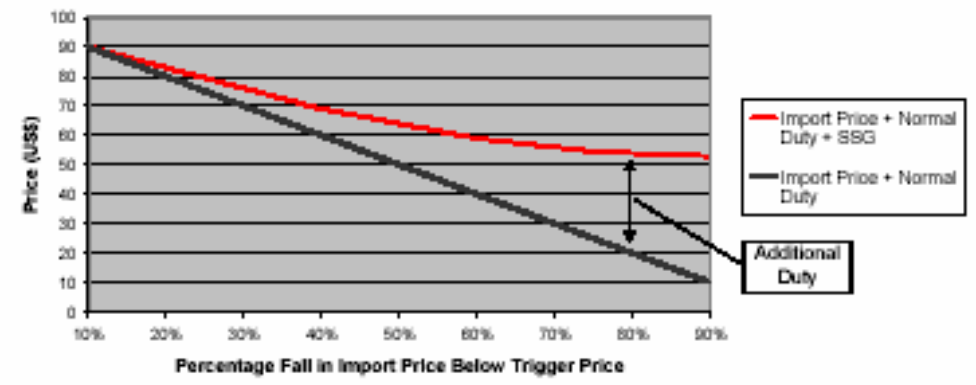

Source: Ruffer and Vergano (2002). 
Negotiators will also face trade-offs. Although it has been agreed that the SSM will be for the use of developing countries only, the country eligibility remains unclear. Are all developing countries eligible or only some of them? The question is sensitive because on the one hand the developing country status is self-proclaimed in the WTO and, on the other hand, some WTO members are likely to resist the creation of an SSM if large net exporters are eligible.

In addition, country eligibility will affect product coverage. If all or most developing countries are eligible then the product coverage needs to be limited. Otherwise, the SSM may undermine liberalization commitments. Many developing countries insist on being allowed to self-determine the product coverage ${ }^{19}$ and initial discussions on modalities left that option open (WTO, 2002c). ${ }^{20}$ However, some WTO members argued that only products undergoing significant tariff reductions should be eligible to the SSM. The trade-off between country and product eligibility also affects the design of the appropriate trigger level. If a large number of countries are eligible and the SSM can cover a substantial part of their agricultural tariff lines, tougher triggers than the one applied in the SSGs are needed to preserve liberalization agreement.

The issue of product coverage is crucial for the actual outcome of the liberalization negotiations under the Doha Round because gains from agricultural liberalization are extremely sensitive to the exclusion of some products. A frequent recourse to the SSM would limit the impact of liberalization and would have a similar impact than special products. Anderson and Martin (2005) provide an illustration of the sensitiveness of agricultural liberalization contemplated in the Doha Round: they showed that three-quarter of the welfare gains from cut in agricultural subsidies and reduction in tariff would disappear if developped countries exclude only 2 percent of products (and developing countries exclude 4 percent) for as sensitive and special products. In addition, the poverty impacts of a Doha agreement would be virually eliminated (Hertel and Winters, 2005).

\section{Conclusions}

Special agricultural safeguards were created during the Uruguay Round in order to obtain greater market opening, and were intended to expire at the end of the transition period to a tariff-only regime. However, special agricultural safeguards will live on. In the Doha Round, some countries asked for the extension of the SSGs, and the creation of a similar mechanism open only to developing countries has been agreed.

However, past experience with the SSGs suggests that special safeguards can threaten the liberalization gains because they can be used as an almost continuous protectionist device.

\footnotetext{
19 That is the case for example of the so-called "friends of special products" group.

${ }^{20}$ Paragraph 23b of Harbinson paper indicated: "Whether, in the framework of special and differential treatment, a new safeguard mechanism and/or countervailing measure for developing countries should be established and, if so, for all agricultural products or for a limited number of products such as strategic/food security/livelihood products? Detailed possible modalities for such provisions have been submitted" (p.6, emphasis added).
} 
Thus, in order to limit the risk for the SSM to become a protectionist device, this paper concludes that:

- A prolonged use of the SSM should be precluded. This can be achieved by explicitly limiting the possibility to invoke safeguards year after year or/and by requesting proof of injury.

- The use of the SSM should be prohibited when markets are closed, because special safeguards are the counterpart of liberalization and improved market access.

- For the same reason, the additional duty should take the form of an ad valorem duty applied on a non discriminatory basis. The use of quantitative restrictions should be ruled out. They would make the SSM costlier to manage, less transparent, and more likely to be used as a protectionist device.

- Notification and transparency requirements should be strongly enforced. Otherwise, as past experience has shown, they risk being ignored, and the use of the safeguard as a protection is made easier.

Moreover, negotiators will face a trade-off between country eligibility and product eligibility. The larger the country eligibility, the smaller should be the product coverage. Since the special safeguards are likely to be available to most of the WTO membership, a limited product coverage seems imperative. Otherwise, liberalization gains from the Doha Round could vanish. 


\section{References}

Anderson, Kym, and Will Martin, 2005, Agricultural Trade Reform and the Doha Development Agenda (Washington: World Bank). Available via the internet: http://web.worldbank.org/WBSITE/EXTERNAL/TOPICS/TRADE/0, contentMDK:2050 8607 menuPK:167367 pagePK:64020865 piPK:51164185 theSitePK:239071,00.html

ERS/USDA, WTO Agricultural Trade Policy Commitments Database. Available via the internet: http://www.ers.usda.gov/db/Wto/WtoTariff_database/.

FAO, 2003, WTO Agreement on Agriculture: The Implementation Experience-Developing Country Case Studies (Rome: FAO). Available via the internet: http://www.fao.org/DOCREP/005/Y4632E/y4632e00.htm.

Hertel, Thomas W., and L. Alan Winters, 2005, Poverty Impacts of a WTO Agreement: Synthesis and Overview (Washington: World Bank). Available via the internet: http://www.gtap.agecon.purdue.edu/resources/download/2103.pdf.

MAFF (Ministry of Agriculture, Forestry, and Fisheries of Japan), 2001, Elaboration of Japan's Negotiating Proposal: A New Safeguard Mechanism. Available via the internet: www.maff.go.jp/wto/wto_syousai newsg_eng.pdf.

OECD, Agricultural Policies in OECD Countries - Monitoring and evaluation, Paris: OECD, various issues.

Official Journal of the European Communities, 2001, L 279, Vol. 44 (October). Available via the internet: http://europa.eu.int/eur-lex/en/archive/2001/1 27920011023en.html.

Oryza, 2002, Oryza Market Report-Costa Rica, November 15. Available via the internet:http://oryza.com/latinamerica/costarica/index.shtml.

Ruffer, Tim, and Paolo Vergano, 2002, An Agricultural Safeguard Mechanism for Developing Countries, Report commissioned by DFID. Available via the internet: http://www.opml.co.uk/docs/ACF3043.pdf.

Somwaru, Agapi, and David Skully, 2003, Will Special Agricultural Safeguards Advance or Retard LDC Growth and Welfare? A Dynamic General Equilibrium Analysis, presented at the Sixth Annual Conference on Global Economic Analysis, The Hague, Netherlands. Available via the internet: http://www.gtap.agecon.purdue.edu/resources/res display.asp?RecordID=1300.

WTO, 2000, Special Agricultural Safeguard, Background Paper by the Secretariat, G/AG/NG/S/9. Available via the internet: http://www.wto.org. 
,2002a, Special Agricultural Safeguard, Background Paper by the Secretariat, G/AG/NG/S/9/Rev.1. Available via the internet: http://www.wto.org.

, 2002b, WTO Negotiations on Agriculture-A Special Agricultural Safeguard Mechanism for Developing Countries and Small Developing Economies, negotiating proposal on behalf of Members of the Caribbean Community (CARICOM), proposal tabled at the Special Session of the Committee on Agriculture Informal Meeting (February). Available via the internet:

http://www.moa.gov.jm/policies/wto3special_session_of the committee.htm.

,2002c, Negotiations on Agriculture-Overview, Committee on Agriculture, Special Session, TN/AG/6. Available via the internet: http://www.wto.org.

,2003a, Negotiations on agriculture-First Draft of modalities for the further commitments, Committee on Agriculture, Special Session, TN/AG/W/1. Available via the internet: http://www.wto.org.

,2003b, Negotiations on agriculture-First Draft of modalities for the further commitments - Revision, Committee on Agriculture, Special Session, TN/AG/W/1/Rev.1. Available via the internet: http://www.wto.org.

, 2004a, Free Trade Agreement Between The United States And Chile, Committee on Regional Trade Agreements, WT/REG160/1. Available via the internet:

http://www.ustr.gov/new/fta/Chile/final/index.htm.

, 2004b, Doha Work Programme-Decision Adopted by the General Council on 1 August 2004, WT/L/579. Available via the internet: http://www.wto.org.

,2004c, Trade Policy Review_European Communities (Geneva: WTO).

, WTO analytical index: Agreement on Agriculture. Available via the internet:

http://www.wto.org/english/res_e/booksp_e/analytic_index_e/agriculture_01_e.htm\#article5B. 


\section{Formula for the Calculation of the Additional Duty \\ 1. The price-based SSGs}

The price-based special safeguards may be taken on a shipment-by-shipment basis using the following formula:

If

$$
\begin{array}{lll}
\mathrm{D} \leq 10 \% & \text { then } \mathrm{t}=0 \\
10 \%<\mathrm{D} \leq 40 \% & \text { then } \mathrm{t}=0.27\left(\mathrm{P}_{\mathrm{T}} / \mathrm{P}_{\mathrm{M}}\right)-0.3 \\
40 \%<\mathrm{D} \leq 60 \% & \text { then } \mathrm{t}=0.39\left(\mathrm{P}_{\mathrm{T}} / \mathrm{P}_{\mathrm{M}}\right)-0.5 \\
60 \%<\mathrm{D} \leq 75 \% & \text { then } \mathrm{t}=0.47\left(\mathrm{P}_{\mathrm{T}} / \mathrm{P}_{\mathrm{M}}\right)-0.7 \\
\mathrm{D}>75 \% & \text { then } \mathrm{t}=0.52\left(\mathrm{P}_{\mathrm{T}} / \mathrm{P}_{\mathrm{M}}\right)-0.9
\end{array}
$$

Where $\mathrm{P}_{\mathrm{M}}=$ the current c.i.f. import price of the shipment expressed in domestic price.

$\mathrm{P}_{\mathrm{T}}=$ the trigger price (the average c.i.f. price for 1986-88)

$\mathrm{D}=\left(\mathrm{P}_{\mathrm{T}}-\mathrm{P}_{\mathrm{M}}\right) / \mathrm{P}_{\mathrm{T}}$; the percentage fall in the import price below the trigger price.

$\mathrm{t}=$ the additional ad valorem duty.

Figures 4 provides and illustration of this formula

\section{The volume-based SSGs}

The volume-based SSGs may be taken in any year when:

$$
\mathrm{M}>\mathrm{Mt}=\mathrm{M}_{\mathrm{AV}} \mathrm{X}+\mathrm{Y}
$$

Where: $\quad \mathrm{M}=$ the absolute volume of imports

$\mathrm{Mt}=$ the trigger level of imports

$\mathrm{M}_{\mathrm{AV}}=$ the average quantity of imports during the three preceding years for which data are available

$\mathrm{Y}=$ the absolute volume change in domestic consumption of the product in the most recent year for which data are available compared to the preceding year.

$\mathrm{X}=$ the base trigger level which equals to

$$
\begin{array}{ll}
105 \% & \mathrm{M} / \mathrm{C}>30 \% \\
110 \% & \text { if } 10 \%<\mathrm{M} / \mathrm{C} \leq 30 \% \\
125 \% & \text { if } \mathrm{M} / \mathrm{C} \leq 10 \%
\end{array}
$$

where: $\mathrm{M} / \mathrm{C}$ is the share of imports in domestic consumption during the three preceding years.

In such a case an additional duty can be imposed. It shall not exceed $1 / 3$ of the level of the ordinary duty in effect and be maintained only until the end of the year in question.

Source: FAO (2003). 
II. Notifications to the WTO

\begin{tabular}{|c|c|c|c|c|c|c|c|c|c|c|c|}
\hline & \multirow{2}{*}{$\begin{array}{l}\% \text { of tariff } \\
\text { line covered } \\
\text { by SSG }\end{array}$} & \multicolumn{9}{|c|}{ Number of SSGs Invoked in } & \multirow[b]{2}{*}{2004} \\
\hline & & 1995 & 1996 & 1997 & 1998 & 1999 & 2000 & 2001 & 2002 & 2003 & \\
\hline Australia & 2 & 0 & 0 & 0 & 0 & 0 & 0 & 0 & 0 & 0 & \\
\hline Barbados & n.a & 0 & 0 & 0 & 0 & 0 & 0 & 0 & 22 & & \\
\hline Botswana & n.a & 0 & 0 & & & & & & & & \\
\hline Bulgaria & n.a & - & - & 0 & 0 & 0 & 0 & 0 & 0 & 0 & \\
\hline Canada & 10 & 0 & 0 & 0 & 0 & 0 & 0 & 0 & 0 & $\mathrm{H} 1: 0$ & \\
\hline Colombia & 27 & 0 & 0 & 0 & 0 & 0 & 0 & 0 & 0 & 0 & \\
\hline Costa Rica & 13 & 0 & 0 & 0 & 0 & 4 & & & 3 & & \\
\hline Czech Rep. & 13 & 0 & 0 & 0 & 0 & 0 & 0 & 5 & 12 & 8 & \\
\hline Ecuador & n.a & - & 0 & 0 & 0 & 0 & 0 & & & & \\
\hline El Salvador & 10 & 0 & 0 & 0 & 0 & 0 & 0 & 0 & 0 & & \\
\hline EC & 31 & 12 & 61 & 60 & 35 & 36 & 36 & 40 & & & \\
\hline Guatemala & n.a. & 0 & 0 & 0 & 0 & 0 & 0 & 0 & 0 & 0 & \\
\hline Hungary & 60 & 0 & 0 & 0 & 0 & 7 & 7 & 7 & 7 & 7 & 7 \\
\hline Iceland & 40 & 0 & 0 & 0 & 0 & 0 & 0 & 0 & 0 & $\mathrm{H} 1: 0$ & \\
\hline Indonesia & 1 & 0 & 0 & 0 & 0 & 0 & 0 & & & & \\
\hline Israel & n.a. & 0 & 0 & 0 & 0 & 0 & 0 & 0 & 0 & 0 & \\
\hline Japan & 12 & 4 & 36 & 5 & 5 & 9 & 8 & 12 & 8 & 20 & 13 \\
\hline Republic of Korea & 8 & 3 & 5 & 9 & 7 & 8 & 20 & & & & \\
\hline Malaysia & 5 & 0 & 0 & 0 & 0 & & & & & & \\
\hline Mexico & 29 & 0 & 0 & 0 & 0 & 0 & & & & & \\
\hline Morocco & n.a. & 0 & 0 & 0 & 0 & 0 & 0 & 0 & 0 & & \\
\hline Namibia & 39 & 0 & 0 & 0 & 0 & 0 & & & & & \\
\hline New Zealand & $<0.5$ & 0 & 0 & 0 & 0 & 0 & 0 & 0 & 0 & 0 & \\
\hline Nicaragua & n.a & 0 & 0 & 0 & 0 & 0 & 0 & 0 & 4 & & \\
\hline Norway & 49 & 0 & 0 & 0 & 0 & 0 & 0 & 0 & & & \\
\hline Panama & n.a & - & - & 0 & 0 & 0 & 0 & 0 & 0 & 0 & \\
\hline Philippines & 13 & 0 & 0 & 0 & 0 & 0 & 0 & 0 & 7 & & \\
\hline Poland & 66 & 0 & 2 & 4 & 6 & 107 & 10 & 6 & 124 & 6 & 88 \\
\hline Romania & 7 & 0 & 0 & 0 & 0 & 0 & 0 & 0 & 0 & & \\
\hline Slovak Rep. & 13 & 0 & 0 & 1 & 0 & 0 & 0 & 0 & 0 & 4 & \\
\hline South Africa & 39 & 0 & 0 & 0 & 0 & 0 & 0 & 0 & 0 & & \\
\hline Swaziland & 39 & & & & & & & & & & \\
\hline Switzerland-Liechtenstein & 59 & 0 & 0 & 0 & 0 & 7 & 0 & 0 & 0 & 0 & 0 \\
\hline Taiwan Province of China & n.a. & - & - & - & - & - & - & - & 39 & 72 & 50 \\
\hline Thailand & 11 & 0 & 0 & 0 & 0 & 0 & 0 & 0 & 0 & & \\
\hline Tunisia & 4 & 0 & 0 & 0 & 0 & 0 & 0 & 0 & 0 & & \\
\hline United States & 9 & 20 & 49 & 74 & 80 & 35 & 37 & 44 & 53 & & \\
\hline Uruguay & $<0.5$ & 0 & 0 & 0 & 0 & 0 & 0 & 0 & 0 & 0 & \\
\hline Venezuela & 31 & 0 & 0 & 0 & 0 & & & & & & \\
\hline Total & & 39 & 153 & 153 & 133 & 213 & 118 & 114 & 279 & 117 & 158 \\
\hline
\end{tabular}

Source: WTO $(2000,2002 a)$ and author's calculation based on notifications to the WTO as of endMay, 2005.

Notes: $\quad$ - : not yet WTO member.

Shaded area: no notification received by the WTO.

H1: notifications covering the first semester of the year. 


\section{Share of Agricultural Lines for Which Countries Have Reserved the Right to Have Recourse to a SSG: Breakdown by Commodities ${ }^{21}$}

A. EC (2002 tariff schedule)

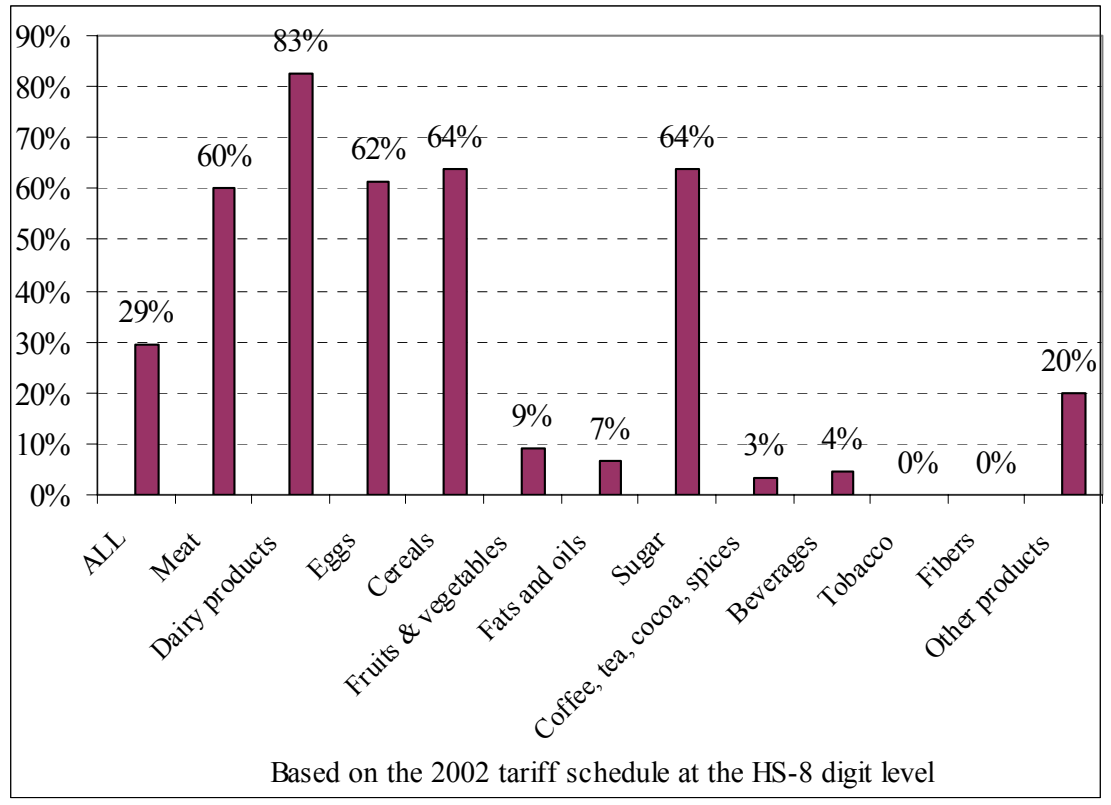

B. Japan (2002 tariff schedule)

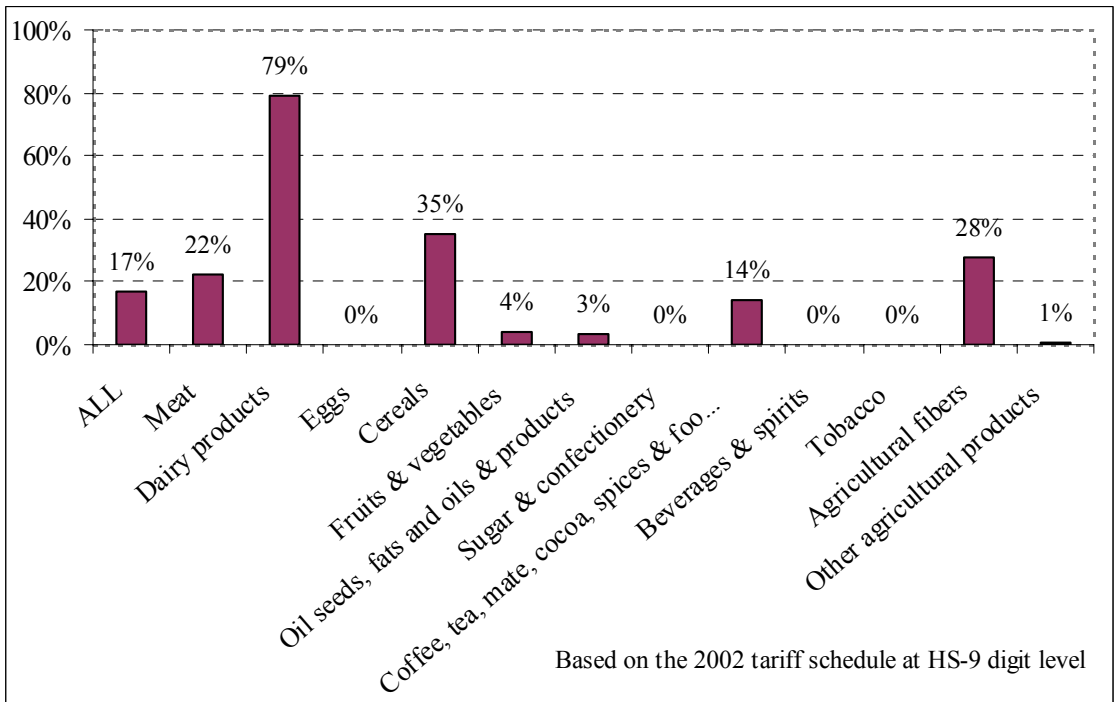

${ }^{21}$ Adjustments were necessary to reflect changes in the nomenclature since 1995 . Therefore, the percentage may differ from Appendix I. 


\section{Tariff Quotas and the SSGs}

\begin{tabular}{|c|c|c|}
\hline & $\begin{array}{l}\text { Countries with Tariff } \\
\text { Quotas } \\
\text { (43 WTO members) }\end{array}$ & $\begin{array}{l}\text { Countries that have reserved the } \\
\text { right to invoke the SSGs } \\
\text { (39 WTO members) }\end{array}$ \\
\hline Australia & $\mathrm{X}$ & $\mathrm{X}$ \\
\hline Barbados & $\mathrm{X}$ & $\mathrm{X}$ \\
\hline Botswana & & $\mathrm{X}$ \\
\hline Brazil & $\mathrm{X}$ & \\
\hline Bulgaria & $\mathrm{X}$ & $\mathrm{X}$ \\
\hline Canada & $\mathrm{X}$ & $\mathrm{X}$ \\
\hline Chile & $X$ & \\
\hline China & $\mathrm{X}$ & \\
\hline Colombia & $\mathrm{X}$ & $\mathrm{X}$ \\
\hline Costa Rica & $\mathrm{X}$ & $\mathrm{X}$ \\
\hline Croatia & $\mathrm{X}$ & \\
\hline Czech Republic & $\mathrm{X}$ & $\mathrm{X}$ \\
\hline Dominican Republic & $\mathrm{X}$ & \\
\hline Ecuador & $\mathrm{X}$ & $\mathrm{X}$ \\
\hline El Salvador & $\mathrm{X}$ & $\mathrm{X}$ \\
\hline $\mathrm{EC}$ & $\mathrm{X}$ & $\mathrm{X}$ \\
\hline Guatemala & $\mathrm{X}$ & $\mathrm{X}$ \\
\hline Hungary & $\mathrm{X}$ & $\mathrm{X}$ \\
\hline Iceland & $\mathrm{X}$ & $\mathrm{X}$ \\
\hline Indonesia & $\mathrm{X}$ & $\mathrm{X}$ \\
\hline Israel & $\mathrm{X}$ & $\mathrm{X}$ \\
\hline Japan & $\mathrm{X}$ & $\mathrm{X}$ \\
\hline Republic of Korea & $\mathrm{X}$ & $\mathrm{X}$ \\
\hline Latvia & $\mathrm{X}$ & \\
\hline Lithuania & $\mathrm{X}$ & \\
\hline Malaysia & $\mathrm{X}$ & $\mathrm{X}$ \\
\hline Mexico & $\mathrm{X}$ & $\mathrm{X}$ \\
\hline Morocco & $X$ & $X$ \\
\hline Namibia & & $\mathrm{X}$ \\
\hline New Zealand & $\mathrm{X}$ & $\mathrm{X}$ \\
\hline Nicaragua & $\mathrm{X}$ & $\mathrm{X}$ \\
\hline Norway & $\mathrm{X}$ & $\mathrm{X}$ \\
\hline Panama & $\mathrm{X}$ & $\mathrm{X}$ \\
\hline Philippines & $\mathrm{X}$ & $\mathrm{X}$ \\
\hline Poland & $\mathrm{X}$ & $\mathrm{X}$ \\
\hline Romania & $\mathrm{X}$ & $\mathrm{X}$ \\
\hline Slovak Republic & $\mathrm{X}$ & $\mathrm{X}$ \\
\hline Slovenia & $X$ & \\
\hline South Africa & $\mathrm{X}$ & $\mathrm{X}$ \\
\hline Swaziland & & $\mathrm{X}$ \\
\hline Switzerland-Liechtenstein & $\mathrm{X}$ & $\mathrm{X}$ \\
\hline Taiwan Province of China & $\mathrm{X}$ & $\mathrm{X}$ \\
\hline Thailand & $\mathrm{X}$ & $\mathrm{X}$ \\
\hline Tunisia & $\mathrm{X}$ & $\mathrm{X}$ \\
\hline United States & $\mathrm{X}$ & $\mathrm{X}$ \\
\hline Uruguay & & $\mathrm{X}$ \\
\hline Venezuela & $X$ & $\mathrm{X}$ \\
\hline
\end{tabular}

Source: WTO. 